\title{
The Dynamics of Sustainable Regime Continuity of China
}

\author{
Mingyue Wen \\ School of Government, Nanjing University, Nanjing, China \\ Email: mingyuewen@hotmail.com
}

How to cite this paper: Wen, M. Y. (2018). The Dynamics of Sustainable Regime Continuity of China. Chinese Studies, 7, 59-71.

https://doi.org/10.4236/chnstd.2018.71006

Received: January 17, 2018

Accepted: February 23, 2018

Published: February 26, 2018

Copyright (C) 2018 by author and Scientific Research Publishing Inc. This work is licensed under the Creative Commons Attribution International License (CC BY 4.0).

http://creativecommons.org/licenses/by/4.0/ cc) (i) Open Access

\begin{abstract}
In the light of various epidemic problems, such as inequality, inequity, corruption, and continual mass protests, is regime collapse in China probable? What are the necessary and sufficient conditions for the occurrence of regime collapse and continuity? To address these questions, I conducted field research in PRC in 2007-2016 to analyze the basic governance problems of the Communist Party of China to generate a basis for predicting China's political development. The key findings are that China's political development is indeed at the crossroads, that regime succession advocates do have the leverage to transform PRC into a capitalist-political system, but that sustainable regime continuity will be enhanced if certain sufficient conditions are present. My principal conclusions are that a dynamic gaming relation is in existence in such a way that both the CPC leadership and regime succession advocates could maneuver at the presence of certain necessary conditions as well as the creation of sufficient conditions for regime continuity or succession. Moreover, once the issues of ideological misfit and governance legitimacy are resolved by theoretical breakthrough, which is already in progress, CPC's sustainable regime continuity will be enhanced. Furthermore, the CPC leadership may well be remembered historically for its contribution to pushing China into a prosperity age, characterized not only by political stability, economic prosperity, and societal harmony, but also the vanishing of exploitation, oppression, and avoidable pain and agony, as well as the flourishing of human growth and development, productivity, and sustainable happiness.
\end{abstract}

\section{Keywords}

China, Human Growth and Development, Marxism, Optimal Governance, Regime Collapse

\section{Introduction}

The economic development of the People's Republic of China (PRC) in the past 
three decades has been impressive. The achievement, however, is accomplished by such serious problems as inequality, inequity, epidemic corruption, and continual mass protests (Harwit, 2014; Zheng, 2012), which may trigger regime collapse. But is it probable? What are the necessary and sufficient conditions for the occurrence of regime collapse and continuity? To address these questions, I conducted field research in PRC in 2008-2016 to analyze the basic governance problems of the Communist Party of China (CPC) to generate a basis for predicting PRC's political development. The research methods used were literature review, field observation, and in-depth interview. The analytic approach employed was pro-active, strategic analysis.

It should be noted that, in the past, China watchers' predictions were primarily based macro-level institutional information analysis. Absent were micro-level empirical data and strategic analysis focusing on deeper level regularities of political preferences and behavioral tendencies of stakeholders to shed light on the dynamic relationships between regime collapse and continuity and, in turn the probable occurrence of collapse or continuity. My study had deviated from the traditional approach, research design, and value perspective employed by China watchers but succeeded in generating pertinent propositions and implications for researchers and political practitioners. My findings are presented in the following pages---in brief, I analyzed in Section 2 a basic issue of PRC's political development, and then the formation of necessary conditions for regime collapse in Section 3; I then presented my strategic analysis of the feasible creation of a sufficient condition for regime collapse in Section 4, my proactive analysis of the likely presence of a sufficient condition for regime continuity, and my strategic analysis of how a sufficient condition for sustainable regime continuity is in creation; Section 7 presents my concluding remarks.

\section{PRC's Political Development at the Crossroads}

After Deng Xiaoping became the supreme leader in 1978, he redefined the essence of PRC, labeling it a country at the primary stage of development of socialism with the mission of optimizing productivity for modernization (Mabbett, 1985). Under Deng's leadership, major economic reforms were launched. Eventually, capitalism, free market, and neo-liberalism are legitimized (Gallagher, 2005), displacing socialist values and practices. In such a context of economic Westernization, political observers interested in predicting PRC's political development trajectory have been exploring if PRC may experience drastic political changes in the near future, leading to the demise of the CPC regime (Ogden, 2014).

One stream of studies suggests that as PRC further develops, Western-style democratization would become inevitable. For example, Bruce Gilley (2008, p. 261) proposed:

In my own study of cross-national sources of legitimacy...large deviations from the regression line became nearly impossible above about $\$ 10,000$ GDP per 
capita... meaning that being a democracy was nearly a necessity above this level. China will likely enter this zone around the year 2020.... China is still on schedule for democratization driven by value change-induced legitimacy crisis.

The Gross Domestic Product per capita of China was last recorded at 7,856 US dollars in 2016. Seemingly, the improving economic conditions are forming a basis for Western-style democratization. Further, in view of the seriousness of epidemic corruption and questionable political loyalty of CPC members (Chan \& Chow, 2007), one can hardly dismiss the possibility of CPC's governance in collapse. Indeed, as my field observation and interview have revealed, in the age of globalization, plentiful CPC members, state cadres (non-manual employees on government payroll), and educated citizens, particularly those who have received American tertiary education, are quite receptive to Western lifestyle, capitalist values, and political practices. While these people have yet to openly advocate the demise of the Chinese Marxist-Leninist system, they have been propagandizing Western political ideas and lifestyles (Zheng, 2012, 2013). Some university faculty members even openly praise in their classrooms American democracy, criticize CPC's malpractices, and question the legitimacy of the CPC regime. All these pro-Western Chinese citizens are in essence regime succession advocates waiting for strategic opportunities to materialize their preference.

Another stream of studies, however, points to the contrary. For example, Guo's (2001) analysis of CPC's monopoly of political power suggests that political monism can be a sufficient condition for distorting democratization, as procedural democracy in PRC could be turned into a regulated political process. More recently, Gore (2015) employed an integrated political and sociological approach in his study to show that CPC could undertake various measures to tame political discontent and that the current socio-political changes in PRC are insufficient to induce regime collapse.

As of today, the political development of PRC is at the crossroads. The CPC leadership may choose to deploy pragmatic strategies and tactics to avert political upheaval, just as such analysts as Gore (2015) had suggested. Indeed, for example, Xi Jinping, the general secretary of CPC, has already intensified anticorruption efforts to lessen social discontent (Heberer, 2014, 2015). As a result, as plentiful public opinion surveys have indicated, public trust in the CPC leadership has increased (Yang, 2014). Such an increase, however, is hardly an assurance that the citizens would still endorse CPC governance when they have other options.

More important, state cadres' loyalty is still questionable. As employees of the Marxist-Leninist state organs, cadres are de facto power-wielders. Thus, when comparing with ordinary citizens, it is rational for them to uphold CPC's political monism. After all, they are the direct beneficiaries under Marxist-Leninism that prescribes the institutionalization of state cadres' monopoly of political, economic, and social powers. In reality, however, many state cadres do not subscribe to the socialist values propagandized by CPC (Caulfield, 2006). Basing on 
field interviews with hundreds of state cadres in various parts of China, Chan and Chow (2007) had reported that state cadres were in the process of transformation-transforming from power-wielders responsible for serving the citizenry to power-monopolists concerned with self-interest advancement. My field observation and interview have documented the same. Further, corruption has become epidemic while rent-seeking is observable in every policy domain, triggering the public to continually stage protests (Harwit, 2014).

Given that state cadres' self-serving behaviors have induced social discontent and thus created political instability, the CPC leadership has to intensify anticorruption efforts (Heberer, 2015). Consequentially, even such senior cadres as Zhou Yongkang, a premier grade cadre (member of the CPC Politburo Standing Committee, 2007-2012) and Ling Jihua, a deputy-premier grade cadre (Vice Chairman of CPPCC-the National Chinese People's Political Consultative Conference) were prosecuted and then imprisoned. More recently, another deputy-premier grade cadre, Sun Zhengcai, was under disciplinary investigation for corruptive practices. Such a hard-nose approach is becoming a threat to almost all state cadres, who one way or the other have committed such wrongdoings as accepting bribes and misusing authority to self-serve. Choosing between living under threat for the rest of their lives and regime collapse, the latter is indeed a much preferred option to them.

\section{The Necessary Conditions for Regime Collapse}

The aforementioned social and political contradictions, however, may not trigger regime collapse. The crucial factor is the underlying logics of decision-making of state cadres and citizens, which could determine actual political outcomes, particularly the rejection of CPC governance. I had conducted a study (2018) involving laboratory experiment and longitudinal interview to explore if Chinese citizens generally and state cadres in particular are rule-abiding beings. The findings suggest that they are indeed rule-abiding beings observing both formal and informal rules, even though their hidden motives may be different. This means that state cadres and citizens may not strive to reject CPC governance after new rules that prescribe political submission are stipulated and straightly enforced by the Xi administration.

Notwithstanding, my field interviews have also documented that most state cadres and citizens have already become pragmatic-rational beings with their preferences and behavioral tendencies basing on rational calculation for personal interest protection or advancement, just as various researchers have documented (Butterfield, 1982; Caulfield, 2006). The value of pragmatism and instrumental rationality are now in prevalence in China (Chan \& Chow, 2007). Internalization of these values by an individual citizen is merely a micro-level phenomenon. When most members of the same social system subscribe to these same values, it becomes a macro-level phenomenon with systemic effects. In other words, from the social reality construction perspective (Berger \& Luckman, 1966; Hummel, 
1994), an objectified social reality of self-interest-serving is in formation, making it impossible for individual citizens to renovate the pragmatic-rational society and for CPC to use piece-meal reform measures to alter it. As pragmatism and instrumental rationality contradict socialist values and communist ideals, the substantive values of CPC governance are marginalized. Inevitably, its ruling legitimacy is in erosion. In short, the prevalence of pragmatic-rational values in China has already become a macro-level necessary condition for regime collapse.

When the prevalence of pragmatic-rational values and other conditions are intermixed to generate configurative effects, CPC regime collapse becomes probable. One such macro-level condition is CPC's inability to manage paradoxical governance. My field interviews have revealed that, after more than 30 years of economic reforms, CPC is facing a Paradox of Governance-that is, the better the CPC performance in economic development, the greater the citizen rejection of its governance. The causes of the paradox are as follows: Firstly, rapid economic development in the past decades has generated tremendous wealth at massive scale for many people, who inevitably long for a political system that builds on and safeguards the right to property. And secondly, in the context of globalization of American culture, the opening-up of China since the 1980s has promoted Chinese people's receptivity to Western political and socio-economic culture and lifestyle. As a result, the Western democracy model has become an attractive alternative. In short, CPC is now in a catch-22 situation, in which CPC must enhance development of PRC in order to justify its ruling legitimacy, but development would in turn undermine its legitimacy.

Erosion of legitimacy may or may not trigger regime collapse. The devastating effect of the Paradox of Governance is conditioned by a meso-level paradox, namely, the Paradox of Cadre Commitment-that is, state cadres as power wielders are committed to both the continuity and demise of the Marxist-Leninist regime. As reported above, my field interviews have documented that most state cadres are now unreceptive to socialist values and communist ideology. Instead, they are concerned with their personal well-beings. More importantly, to facilitate further monopoly of economic and political powers for optimal benefits, cadres have strengthened collaboration with their counterparts in the economic sphere. In the process, many cadres have undertaken unlawful and/or unethical actions to generate great wealth. Their behaviors have alienated the citizenry and thus triggered continual mass protests. In view of the increasing political instability, the $\mathrm{Xi}$ administration has intensified anti-corruption efforts since 2012, sending even senior cadres to jail. As a result, state cadres are now apprehensive about the forthcoming disciplinary actions. They need immunity from punishment and lawful protection of their unlawfully cumulated wealth. They therefore find regime collapse expedient.

The irony of the Paradox of Cadre Commitment to the $\mathrm{Xi}$ administration is thus that state cadres support CPC governance in order to advance their wellbeings, but they also find the demise of CPC governance desirable as wealth con- 
fiscation and imprisonment might be avoided. Expectedly, Xi's intensification of anti-corruption would reinforce cadres' decision to endorse regime succession. As power wielders, cadres are influential in China. Given the prevalence of pragmatism and instrumental rationality and in the light of the Paradox of Governance, their endorsement of the political transformation proposal could make regime collapse ineluctable.

\section{A Sufficient Condition for Regime Collapse}

In the light of the aforementioned paradoxes and in view of the fact that most state cadres and citizens are pragmatic-rational beings, one may suggest that the necessary conditions for regime collapse are present and thus PRC may indeed be "on schedule for democratization" as Gilley (2008) has suggested. Nonetheless, citizen preference is malleable. On the one hand, the contemporary Chinese might still accept regime continuity if CPC could convince them that its governance might eventually generate optimal development of PRC that benefits all citizens. And on the other hand, they might accept regime collapse if regime succession advocates could present reform measures which not only better safeguard citizen rights but also optimization of various benefits for most stakeholders.

The key factor that determines citizen preference is the convincingness of regime continuity (to be provided by the CPC leadership) and regime succession (provided by the regime succession advocates). My field interviews reveal that this convincingness is to be judged by a basic cultural prescription observed by the contemporary Chinese: reform must generate Pareto improvement. Regime succession advocates' underlying this prescription is essential to their developing an attractive political transformation package. Consider the Chinese Jasmine Revolution (February-May, 2011). It was a total failure due to the fact that the calling for civil rights and political reform was appealing to only a small fraction of the citizenry. Without mass support, the Jasmine Revolution was easily cracked down (for a listing of various news reports, see https://en.wikipedia.org/wiki/2011_Chinese_pro-democracy_protests). By the same token, if contemporary regime succession advocates merely present a new institutionalization scheme that models after the American political system, political support will be meager. After all, both workers and peasants would consider the institutional reform beneficial only to the upper and middle class citizens, while state cadres as power wielders may find it detrimental to their political and socio-economic interests.

From a strategic perspective, to enhance the convincingness of their proposal, regime succession advocates must become more politically articulate. Rather than merely advocating democratic values, they need to focus on the critical concerns of the citizenry and then design an attractive package of value realization. First, basing on field interviews with people from all walks of lives in various provinces, I have found that freedom, justice, equality, and rule-of-law are 
four basic political values treasured by most contemporary Chinese, of which political monism may not assure. As such, the citizenry is very likely to be receptive to Western style democratization reform if these values are highlighted and guaranteed in a detailed regime succession proposal to be presented by the advocates. Further, the advocates should use a tactical propaganda-endorsing Xi Jinping's advocacy of the Chinese dream of rejuvenating China but reshaping it into a Chinese dream of making freedom, justice, equality, and rule-of-law the hallmark of modern China. Such a tactic is likely to allow the advocates greater leeway in creating massive political support.

Second, to turn receptivity into political commitment and active support, advocates must present detailed, attractive Pareto improvement measures in their regime succession proposal. In the light of the field research findings reported above, it can be suggested that the most attractive reform proposal that comes with the demise of the Marxist-Leninist system is asset redistribution, which would please the pragmatic-rational citizens. For example, according to the Ministry of Finance, the total asset of state-owned enterprises was 104.4 trillion $\mathrm{RMB}$ in 2013 (http://www.cinn.cn/qiy/qyzh/321229.shtml). If the regime succession advocates propose to turn the state-owned assets into unit trust fund equally shared by the 1.38 billion Chinese, with each receiving 75,000 RMB (approximately US\$12,000), citizens would consider it desirable to dismantle the Marxist-Leninist system. In addition, all natural resources are currently owned by the state. Should such measures as having a portion of the income from the harvesting of natural resources evenly shared by all citizens and distributed in cash annually, the citizenry would surely find the regime succession proposal irresistible.

And third, as almost all state cadres have had a record of misbehaviors, political transformation advocates must highlight the mechanics of "victimization of cadres" under political monism-that is, cadres are conditioned by the political system to become wicked in order to survive. By doing so, cadres with disgraceful conduct would be considered as victims of the Marxist-Leninist system and thus should be socially pardoned. Inevitably, most cadres would become wholehearted supporters of regime collapse. Further, the advocates should propose the inclusion of a grandfather clause in the new constitution to grant state cadres immunity from punishment for their wrongdoings conducted in the past. Such a measure would surely generate cadres' full support.

All in all, in the light of the cultural preference of Pareto improvement and in view of the pragmatic-rational tendencies of state cadres and citizens, regime succession advocates could create a sufficient condition for CPC's regime demise by presenting a reform package that would benefit almost all stakeholders. Regime collapse could take place as soon as the advocates make good use of some typical social protests to bring about a decisive political showdown.

\section{A Sufficient Condition for Regime Continuity}

It should be noted, however, that timing is of essence. In brief, it has been a tra- 
dition that public security forces are to take all necessary measures to prevent any disturbing incidents from happening before and during the plenary sessions of CPC National Congress. Thus, the actions to be undertaken by the political transformation advocates in 2017 were doomed to fail as the $19^{\text {th }}$ CPC National Congress was in session in November. Further, my political analysis of the bio-data of members of the CPC Central Committee shows that a large number of the members who rose to power in the Jiang Zemin era (1989-2004) would retire at the 19th CPC National Congress. The succession of leading cadres would result in the consolidation of Xi Jinping's political control of CPC and in turn the country, making regime collapse difficult.

More important, after the first plenary session of the 19th CPC National Congress, $\mathrm{Xi}$ is free to accomplish his self-defined missions. One top-prioritized sacred mission is the reunification of China before the Centennial Anniversary of the founding of CPC (2021). Reunification by force has already been deemed viable when necessary, and thus full scale military preparations have been made since 2012 . When PRC is fully ready militarily by 2020 , ultimatum will be given to the Taiwan government. If refused, invasion will follow. In the light of the substantial military build-up and decisive strike force superiority, reunification is likely to be accomplished in late 2020. Xi will of course avoid invasion if the Taiwan leaders are willing to sign accord of peaceful reunification before the CPC Centennial Anniversary. Regardless, CPC's efforts to reunite China by force will be organized, and massive scale propaganda will be made. Inevitably, aspiration of national unity and patriotic sentiment will then be intensified. As a result, political support to CPC will mount. The rally 'round the flag effect will be generated, making political transformation an insignificant issue to patriotic citizens. This means that the CPC governance legitimacy will no longer be an issue after 2019. In short, Xi's determination to reunite China by force is in essence a sufficient condition for $\mathrm{CPC}$ regime continuity.

If $\mathrm{Xi}$ for whatever reasons lacks a strong will to enhance reunification by force, the story will be quite different. In view of his strong leadership performance in the past five years, however, his backing down is very unlikely. After all, accomplishing the reunification mission before the CPC Centennial Anniversary will be accorded with historical significance, and the accomplisher will be well praised. All these mean that the wholesale democratization reform has to be engineered to take place in 2018-19, which is the only time frame for regime succession advocates to maneuver. Or else the window of opportunity will be closed.

\section{A Sufficient Condition for Sustainable Regime Continuity}

The analysis above has shown that a dynamic gaming relation is in existence so that the CPC leadership and regime succession advocates could maneuver at the presence of certain necessary conditions as well as the creation of sufficient conditions for regime continuity or succession. Indeed, politics is dynamic; so is the 
pursuit of regime continuity or succession. But the gaming may not induce sustainable effects. For example, the CPC leadership may choose to unify China by force so as to effectuate the rally 'round the flag syndrome to generate political support. By the same token, when other countries take a hard-nose approach and hostile measures to deal with confrontational issues, such as territorial dispute and trade war, the CPC propaganda machinery may use the incidents to raise patriotic spirits. In other words, regime succession advocates may succeed if and only if they could maneuver at the absence of international antagonistic conditions.

More important, it should be noted that if the various governance problems and paradoxes mentioned in the preceding pages remain unresolved, there may be new problems at various points of time that trigger citizen anger and resentment, thus again creating opportunities for regime succession advocates to maneuver even after the unification of the country. For example, I have reported elsewhere (2018) that intense politicization in the 1960s-1970s and market reforms launched since 1978 had eroded PRC's ideological basis, making the citizenry unreceptive to CPC's political preaching and governance legitimacy. Student responses in my classroom were revealing. In brief, when I demonstrated in the classroom how to apply principles of Marxism and Mao Zedong thinking to analyze contemporary public affairs issues, both undergraduate and graduate students got bored, while MPA students with job experience found my analysis irrelevant to their real world problem-solving. When my teaching revolved around the formulation of public policies to realize Marxian values, students considered it unnecessary or impractical. All these mean that the CPC leadership must revitalize its governance ideology in order to enhance sustainable regime continuity.

Research (Chow, 2014) has underscored that altruism was a critical factor to success in CPC's heydays (1936-1959). CPC may focus on the altruistic prescription internalized by the Chinese people to neutralize the influences of regime succession advocates. My field interviews are revealing. For example, some hard-core CPC supporters are now puzzled by a basic contradiction or misfit that has salient implication for CPC governance. The misfit lies in the matching between the political reality and ideology. In brief, whereas CPC is in theory the vanguard of the proletariats, the rapid economic development in the past decades has resulted in the formation of bourgeoisie whose property rights are constitutionally protected since the 2004 constitutional amendment (Gallagher, 2005). Plentiful cases have documented that many Chinese capitalists are aggressive in promoting their self-interest through bribery, making "collusion between money and power" a hallmark of CPC governance, particularly at the local level (Chow \& Luo, 2007). As a result, many law-abiding citizens are punished for being incorruptible, while immoral beings are rewarded for their wickedness. In this context, honest capitalists have to compromise, using such means as donation, gift-sending, and wining-and-dinning to avoid alienating the power wield- 
ers. Other citizens have to either lower their expectation of social justice or jump on the bandwagon. In short, the political reality is as such that the ideology of proletariat dictatorship is no longer descriptive of the essence of CPC's governance. The political system is primarily serving state cadres and those who do not hesitate to use illegal and unethical means to self-enrich. Honest capitalists and middle-class professionals may still have their means to excel; in contrast, workers and peasants could have only a nominal share of the cake of economic development.

The CPC leadership has tried to justify the misfit by using the theory of primary stage of development of socialism (Mabbett, 1985). Such a theory calls for the adoption of a pragmatic productivity enhancement approach that embraces capitalism and market mechanism. If workers and peasants are the primary or equal footing beneficiaries under this theory, the ideological misfit is hardly an issue. The income inequality, however, has been rather serious-the Gini coefficient was 0.469 in 2014 (People's Daily, 21 Jan. 2015). Further, diminishing are the political status and influence of workers and peasants-only $18 \%$ of the delegates of the National People's Congress are workers and peasants (as of December 2015), while their representativeness of CPC membership had dropped from $39 \%$ in 2014 to $37.5 \%$ in 2015 (Gore, 2015). Obviously, the theory of primary stage of development of socialism has defects. Inevitably, even some hard-core CPC ideologues are becoming pragmatic-one interviewee had bluntly stated, "as long as the people could live happily, whoever is in charge and whatever system is in place are unimportant." Seemingly, after more than three decades of rapid economic development, socio-economic concerns have overridden ideological insistence.

In the past three years, my field interviews with hard-core ideologues amounted to only six (i.e., $1.1 \%$ of the 536 interviewees). The plain truth is that these ideologues are hard to find, even though there are 88.8 million CPC members (as of December 2015). An inference is that, as there are now only a handful of genuine CPC supporters, the political foundation of CPC governance has seriously eroded. In all fairness, however, one must recall that when CPC was established in 1921, there were 57 members. But in only 28 years, CPC increased the membership to approximately $4.5 \mathrm{M}$ when PRC was established in 1949. It should also be noted that when the CPC leadership insisted on launching a genuine proletariat revolution in the early 1920s, CPC lacked popular support to excel due to the fact that China was an agrarian society. But then, after the leadership reframed the working class revolutionary pursuit in late 1920s to make it a poor people revolution, massive support from the 3 billion-plus peasants was created. In other words, if CPC is to flourish in the 21st Century, it must revitalize the theory and mission of its socialist governance in order to generate citizen support for sustainable regime continuity.

The $\mathrm{Xi}$ administration is aware of the pressing need and has begun to strive to enhance political theory innovation. My field interviews with leading scholars in 
political science and public administration have found that progresses are made. For example, some scholars have redefined proletariats as people with vulnerability in resisting various political, economic, occupational, and emotional exploitation and suppression. With the new definition, the proletariat revolution would become a pursuit of all vulnerable people being united to enhance "justice for all”. As such, CPC is to become the vanguard of vulnerable people and a political party dedicated to creating a just society. Given that people from all walks of life would invariably have suffered from diverse types and various forms of exploitation and suppression in their lifetime, political support to CPC could be massive if such a redefinition of proletariat revolution is officially adopted and propagandized. Further, research (Chow, 2014) has shown that many Chinese people from all walks of life are altruistic beings. They would for sure endorse the redefinition of proletariat to vulnerable people, and also strongly support CPC's governance for altruistic cause.

Another stream of research focuses on human development as a series of stages of developmental progresses, through which sustainable happiness and enduring gratification can be enhanced. The key argument of this school of thought is that people's self-serving orientation and Peter Pan type of personality are only typical at the primary stage of human growth and development, while such behavioral tendencies as sharing and helping are characteristics of the immediate level of human growth and development. Further, at the higher level, people are gratified by their contribution to the well-beings of mankind. Dedication to professionalism, commitment to social responsibility, and keen concern for sustainability (particularly sustainable happiness for all) are typical characteristics of the people at the higher level of human growth and development. My interviewees have reported that the assessment inventory for measuring the degree and extent of human growth and development has already been validated.

According to these researchers, as human growth and development is a series of stages of progresses, CPC should no longer function to merely safeguard citizen rights and strive to enhance Good Governance (i.e., rule-of-law-based governance for citizens' freedom, equality, equity, and justice) as practiced in the West. Instead, CPC's legitimacy must be built on the commitment to and effectiveness in enhancing citizens' sustainable, optimal growth and development in a non-exploitative and non-suppressive context. These propositions constitute a new model of governance, namely, the Optimal Governance (i.e., governance for citizens' optimal growth and development). If CPC strives to institutionalize and effectuate this new model of governance, massive citizen support will be enhanced.

These two streams of research together furnish a solid basis to revitalize the theory and mission of CPC governance. If CPC indeed acts accordingly, its legitimacy of governance and sustainability of regime continuity will be enhanced. Nonetheless, even though this sufficient condition for sustainable regime continuity is much needed, its creation takes time and effort. For example, research- 
ers have yet to receive sufficient funding to launch full-scale research to valid their propositions. Even when funding is generous, it will take time to re-socialize the citizenry. Further, as the redefinition of proletariat revolution and institutionalization of Optimal Governance would induce substantial political and institutional changes, the CPC leadership is unlikely to make hasty decisions as it has developed a habit of conducting natural experiments before adopting innovative policies. Inevitably, the issues of ideological misfit and governance legitimacy will remain unresolved in the near future. But once these issues are resolved by theoretical breakthrough as mentioned above, CPC's sustainable regime continuity will be enhanced.

\section{Concluding Remarks}

In the light of various epidemic problems, such as inequality, inequity, corruption, and continual mass protests, is regime collapse in China probable? To address this question, I conducted field research in PRC in 2007-2016 to analyze the basic governance problems of the Communist Party of China to generate a basis for predicting China's political development. The principal findings presented in the preceding pages are that China's political development is indeed at the crossroads, that regime succession advocates do have the leverage to transform PRC into a capitalist-political system, but that sustainable regime continuity will be enhanced if certain sufficient conditions are present.

In view of the impressive development of China in the past decades, one may speculate that once the CPC leadership resolves the ideological puzzle and undertake rational policy actions to effectuate Optimal Governance, PRC may further prosper by realizing substantially great gains from the actualization of potentials of the citizenry and in turn productivity, creativity, and international competitiveness. Further, the CPC leadership may well be remembered historically for its contribution to pushing China into a prosperity age, characterized not only by political stability, economic prosperity, and societal harmony, but also the vanishing of exploitation, oppression, and avoidable pain and agony, as well as the flourishing of human growth and development, productivity, and sustainable happiness.

Finally, it should be noted that, while my study had deviated from the traditional approach, research design, and value perspective employed by China watchers but succeeded in generating pertinent propositions and implications for researchers and political practitioners, the findings, however, are hardly conclusive as the frequency and scope of field observation are limited and the representativeness of interviewees is questionable. Further research is still much needed.

\section{Funding}

This project (Code: 2016M601780) is funded by the China Postdoctoral Science Foundation 


\section{References}

Berger, P., \& Luckman, T. (1966). The Social Construction of Reality: A Treatise in the Sociology of Knowledge. Penguin Books.

Butterfield, F. (1982). China Alive in Bitter Sea. Times Book.

Caulfield, J. L. (2006). Local Government Reform in China: A Rational Actor Perspective. International Review of Administrative Sciences, 2, 253-267. https://doi.org/10.1177/0020852306064613

Chan, H. S., \& Chow, K. W. (2007). Public Management and Policy in Western China: Metapolicy, Tacit Knowledge, and Implications. American Review of Public Administration, 4, 479-498. https://doi.org/10.1177/0275074006297552

Chow, K. W. (2014). Altruism in Chinese Emergency Management: The Case of Wenchuan Earthquake. In A. Farazmand (Ed.), Crisis and Emergency Management: Theory and Practice (2nd ed., pp. 585-596). New York: CRC Press. https://doi.org/10.1201/b16715-37

Chow, K. W., \& Luo, L. Q. (2007). Rationalizing Public Organizations in Western China: Contending Approaches and Conflicting Logics. Public Organization Review, 1, 69-91. https://doi.org/10.1007/s11115-006-0022-Z

Gallagher, M. E. (2005). China in 2004: Stability above All. Asian Survey, 1, 21-32. https://doi.org/10.1525/as.2005.45.1.21

Gilley, B. (2008). Legitimacy and Institutional Change: The Case of China. Comparative Political Studies, 3, 259-284. https://doi.org/10.1177/0010414007308020

Gore, L. L. P. (2015). The Social Transformation of the Chinese Communist Party: Prospects for Authoritarian Accommodation. Problems of Post-Communism, 4, 204-216. https://doi.org/10.1080/10758216.2015.1037590

Guo, S. (2001). The Party-State Relationship in Post-Mao China. China Report, 3.

Heberer, T. (2014). China in 2013: The Chinese Dream's Domestic and Foreign Policy Shifts. Asian Survey, 54, 113-128. https://doi.org/10.1525/as.2014.54.1.113

Heberer, T. (2015). China in 2014: Creating a New Power and Security Architecture in Domestic and Foreign Policies. Asian Survey, 55, 82-102.

https://doi.org/10.1525/as.2015.55.1.82

Hummel, R. P. (1994). The Bureaucratic Experience (4th ed.). New York, NY: St. Martin's Press.

Mabbett, I. (1985). Modern China: The Mirage of Modernity. New York, NY: St. Martin's Press.

Ogden, S. (2014). Will China Democratize? The China Quarterly, 219, 864-865. https://doi.org/10.1017/S0305741014000794

Yang, Z. (2014). Do Chinese People Trust Their Local Government, and Why? Problems of Post-Communism, 3, 31-44.

Zheng, Y. N. (2012). China in 2011: Anger, Political Consciousness, Anxiety, and Uncertainty. Asian Survey, 52, 28-41. https://doi.org/10.1525/as.2012.52.1.28

Zheng, Y. N. (2013). China in 2012: Troubled Elite, Frustrated Society. Asian Survey, 53, 162-175. https://doi.org/10.1525/as.2013.53.1.162 